\title{
HUMAN PANCREATIC POLYPEPTIDE IN A PHOSPHOLIPID BASED MICELLAR FORMULATION
}

\author{
Amrita Banerjee ${ }^{a}$ and Hayat Onyuksela,b, \\ aDepartment of Biopharmaceutical Sciences, University of Illinois at Chicago, Chicago, Illinois \\ 60612, USA \\ bDepartment of Bioengineering, University of Illinois at Chicago, Chicago, Illinois 60612, USA
}

\begin{abstract}
Purpose-Pancreatic polypeptide (PP) has important glucoregulatory functions and thereby holds significance in the treatment of diabetes and obesity. However, short plasma half-life and aggregation propensity of PP in aqueous solution, limits its therapeutic application. To address these issues, we prepared and characterized a formulation of PP in sterically stabilized micelles (SSM) that protects and stabilizes PP in its active conformation.
\end{abstract}

Methods-PP-SSM was prepared by incubating PP with SSM dispersion in buffer. Peptidemicelle association and freeze-drying efficacy of the formulation was characterized in phosphate buffers with or without sodium chloride using dynamic light scattering, fluorescence spectroscopy and circular dichroism. The degradation kinetics of PP-SSM in presence of proteolytic enzyme was determined using HPLC and bioactivity of the formulation was evaluated by in vitro cAMP inhibition.

Results-PP self-associated with SSM and this interaction was influenced by presence/absence of sodium chloride in the buffer. The formulation was effectively lyophilized, demonstrating feasibility for its long-term storage. The stability of peptide against proteolytic degradation was significantly improved and PP in SSM retained its bioactivity in vitro.

Conclusions-Self-association of PP with phospholipid micelles addressed the delivery issues of the peptide. This PP nanomedicine should be further developed for the treatment of diabetes.

\section{Keywords}

Chronic Pancreatitis; Pancreatic Polypeptide; Pancreatogenic Diabetes; Peptide nanomedicine; Sterically Stabilized Micelles

\section{INTRODUCTION}

Pancreatic polypeptide (PP) is an endogenous peptide hormone secreted by the F cells, also called PP cells of the islets of langerhans of pancreas, mostly postprandially (1). The primary role of $\mathrm{PP}$ is to modulate digestion of food by inhibition of gastric emptying as well as biliary secretion $(2,3)$. PP binds with picomolar affinity to its constitutive Y4 receptor (4) that is expressed in the liver, intestine, adrenal gland and parts of the central nervous system (5). The peptide is reported deficient in chronic pancreatitis (CP) that leads to diabetes known as pancreatogenic diabetes $(\mathrm{PD})$; while its receptor $(\mathrm{Y} 4)$ are overexpressed in the

\footnotetext{
*Address for correspondence: Hayat Onyuksel, Ph.D., Department of Biopharmaceutical Sciences (M/C 865), College of Pharmacy, University of Illinois at Chicago, 833 South Wood Street, Chicago, Illinois 60612-7231, USA, Phone: (312) 996-2097, Fax: (312) 996-0098, hayat@uic.edu.
} 
same disease (6-8). CP is characterized by exocrine and endocrine insufficiency (7) and due to lack of specific guidelines and effective treatment portfolio, management of PD secondary to CP is an unmet medical need. A major shortcoming in the treatment of PD is that insulin and insulin secretogogues increase the risk of development of pancreatic cancer, therefore should be avoided where possible (9). Moreover, absence of ability of pancreas to secrete counter-regulatory hormone glucagon increases the risk for development of severe hypoglycemia as a result of insulin therapy (9).

PP is known to possess significant glucose regulatory function. The peptide sensitizes the liver to the action of insulin by increasing the number of insulin receptors in the hepatocytes (10-12). PP has also been reported to decrease the expression of resistin hormone that plays a major role in the development of hepatic insulin resistance and elevated levels of resistin is reported in CP (13-15). Needless to say, deficiency of the peptide results in significant hepatic insulin resistance $(10,16)$ as well as glucose intolerance which can be attributed to the impairment of hepatic sensitivity to insulin and up regulation of resistin hormone. In patients with diabetes secondary to $\mathrm{CP}$, administration of $\mathrm{PP}$ reverses insulin resistance and improves glucose metabolism (17-19). Administration of PP does not increase serum insulin levels (20), therefore PP therapy can be considered safe. In addition, administration of this peptide reduces appetite and decreases the expression of orexigenic peptides such as neuropeptide Y (NPY) and ghrelin that are responsible for hyperphagia (13). Therefore, PP has a tremendous potential with multiple mechanisms of action in the treatment of pancreatogenic diabetes.

However, the peptide suffers from the problem of short biological half-life that curtails its therapeutic application (21-23) and necessitates administration of PP as continuous intravenous infusion which is patient non-compliant and can lead to development of adverse effects due to higher total dose administered that may interact with off target site receptors in the body. Self-aggregation of PP molecules in aqueous solution is another serious delivery problem of the peptide.

In an attempt to address these issues, we have prepared and characterized a biocompatible and biodegradable micellar formulation of PP that would help counteract the biological instability concern of the peptide. These micelles known as sterically stabilized micelles (SSM) are self-assemblies of polyethylene glycolated (PEGylated) phospholipids that aggregate at concentrations higher than their critical micellar concentration $(\sim 1 \mu \mathrm{M})(24)$. Hydrophobic drugs are solubilized in the lipid core of the micelles $(25,26)$, while amphiphilic peptide drugs are postulated to reside at the PEG palisade and associate with the micelles as monomers that serve to thwart their aggregate formation $(27,28)$. PEG prevents uptake and rapid clearance of these micelles in vivo by the reticulo-endothelial system and also prevents the interaction of the payload with proteolytic enzymes, thus increasing the biological stability and circulation half-life of small molecule drugs $(29,30)$ or peptides $(28,31)$. Previous studies have demonstrated that these lipid micelles significantly enhance the proteolytic stability and biological half-life of peptides such as vasoactive intestinal peptide (27). Owing to its nanosize $(\sim 15 \mathrm{~nm})$, the micelles can be passively targeted through leaky vasculature such as those observed at tumor or inflammation site and through fenestrations in the liver. Micelles due to limited extravasation, also prevents interaction of peptides with their receptors that are expressed in the extra vascular part of healthy tissues, thereby eliminating other undesirable physiological effects of peptides. Furthermore, because of very low critical micellar concentration (CMC), SSM have acceptable stability upon dilution after in vivo administration. These multiple reasons make SSM an ideal delivery platform for peptides such as PP that suffer from issues such as short half-life and self-aggregation. The formulation of PP associated with SSM (PP-SSM), owing to its nanosize can easily extravasate out of circulation through the liver sinusoidal epithelium 
fenestrations and thus be passively targeted to the hepatocytes where the peptide can be internalized by Y4 receptors via receptor mediated endocytosis. Furthermore, due to overexpression of these receptors in chronic pancreatitis, we can anticipate a significant accumulation of PP-SSM in the liver. Targeted delivery and increased in vivo stability of the peptide will also help decrease the required dose for the therapeutic effect. Based on these rationales, we tested SSM as a delivery system for PP and characterized the formulation for its future application as a novel nanomedicine for the treatment of diseases associated with PP deficiencies such as pancreatogenic diabetes (9).

\section{MATERIALS AND METHODS}

\section{Materials}

1,2-Distearoyl-sn-glycero-3-phosphatidylethanolamine-N-

[methoxy(polyethyleneglycol)-2000] sodium salt (DSPE- PEG $_{2000}$ ) was purchased from Lipoid GmbH (Ludwigshafen, Germany). Human pancreatic polypeptide (PP) was prepared at protein research laboratory, research resources center of University of Illinois at Chicago (> 95\% purity as determined by reverse phase high performance liquid chromatography). Phosphate buffered saline (PBS), pH 7.4 was purchased from Mediatech Inc, Manassas, VA. Normal saline ( $0.9 \% \mathrm{w} / \mathrm{v}$ sodium chloride injection USP) was purchased from Baxter Healthcare Corporation (Deerfield, IL). All other buffers were prepared in the laboratory using chemicals purchased from Fisher Scientific (Itasca, IL) or Sigma-Aldrich (St. Louis, MO). Cyclic AMP EIA kit was purchased from Cayman Chemical Company (Ann Arbor, MI). SK-N-MC cells (HTB-10) and eagle's minimum essential media (EMEM) were purchased from American Type Culture Collection (Manassas, VA). The HPLC column used (Varian, Serial No. 379013, Pursuit XRs) had the following specifications - C18, 4.6 × $250 \mathrm{~nm}, 5 \mu \mathrm{m}$. Trypsin-EDTA $(0.25 \%$ with $0.53 \mathrm{mM}$ EDTA) was purchased from Mediatech, Inc. (Manassas, VA). Acetonitrile HPLC grade, trifluoroacetic acid HPLC grade and phosphoric acid HPLC grade were purchased from Fisher Scientific (Itasca, IL).

\section{Preparation of samples}

The formulation of PP associated with SSM (PP-SSM) was prepared based on our previous work with other peptides and SSM $(27,28,31)$. Briefly, weighed quantity of DSPE-PEG 2000 was added to phosphate buffer ( $\mathrm{pH} 6.5,7.4$ or 8.0) or normal saline $(\mathrm{pH} 4.5-7.0)$, vortexed for 2 minutes, (Thermolyne Maxi Mix II) sonicated for 5 minutes (Bransonic Ultrasonic cleaner) and allowed to equilibrate in the dark for $1 \mathrm{hr}$ at $25^{\circ} \mathrm{C}$ to form micelles at a concentration of lipid above its CMC. Weighed quantity of $\mathrm{PP}$ in respective phosphate buffers or normal saline was added to the SSM dispersion and allowed to equilibrate for $2 \mathrm{hr}$ in the dark at $25^{\circ} \mathrm{C}$.

\section{Particle size distribution analysis}

The experiment was performed to study the aggregation behavior of PP in the presence or absence of micelles with the goal of determining whether SSM mitigated the selfaggregation propensity of the peptide. Particle size distribution of empty SSM $(120 \mu \mathrm{M}$ DSPE-PEG 2000$), \mathrm{PP}(4 \mu \mathrm{M})$ and PP-SSM were determined by dynamic light scattering technique using Agilent 7030 NICOMP DLS/ZLS (Agilent Technologies, Santa Clara, CA). All samples were prepared in $\mathrm{pH} 7.4$ phosphate buffered saline. The hydrodynamic diameters $\mathrm{d}_{\mathrm{h}}$ of the particles were obtained utilizing the Stokes-Einstein equation that calculates particle size using from the translational diffusion coefficient of the particles (viscosity $=0.933 \mathrm{cP}$, refractive index $=1.33$, and scattering angle of 90 ). Mean hydrodynamic diameter was calculated using the average of three $\mathrm{d}_{h}$ values using autocorrelation function collected over at least 15 minutes. Both intensity and volume weighted particle size distribution were determined. 


\section{Effect of $\mathrm{pH}$ and sodium chloride on the association of peptide and micelles}

The aim of this study was to investigate whether PP self-associated with micelles and if so to determine the saturation molar ratio of association of the peptide with micelles at different $\mathrm{pHs}$ in the presence or absence of $0.9 \% \mathrm{w} / \mathrm{v}$ sodium chloride. Recent studies in our lab have shown that physico-chemical properties of SSM such as hydrodynamic diameter, aggregation number, critical micellar concentration and viscosity vary with the presence or absence of sodium chloride in the aqueous media of the formulation (32). Furthermore, presence or absence of sodium chloride may alter physico-chemical properties of the peptide, thus influence peptide-micelle association. $\mathrm{pH}$ of the formulation is another parameter that can modify a peptide's aqueous solubility, secondary structure and thus interaction of a peptide with micelles. This study was conducted to understand the influence of these formulation variables on peptide-micelle association. Samples were prepared in $0.9 \% \mathrm{w} / \mathrm{v}$ sodium chloride $(\mathrm{pH} 4.5-7.0)$ or in phosphate buffers of $\mathrm{pH} 6.5,7.4$ and 8.0 with or without $0.9 \% \mathrm{w} / \mathrm{v}$ sodium chloride. Fluorescence emission of tyrosine residues in PP was monitored at excitation wavelength of $277 \mathrm{~nm}$ and emission wavelength of $304 \mathrm{~nm}$ (33) using SLM Aminco 8000 spectrofluorimeter (SLM Instruments, Rochester, NY). Peptide concentration used was $4 \mu \mathrm{M}$ while lipid concentration varied from $8 \mu \mathrm{M}$ to $400 \mu \mathrm{M}$. The maximum emission (I) of each sample was normalized against the fluorescence emission of PP in buffer $\left(\mathrm{I}_{0}\right)$ and this function $\left(\mathrm{I} / \mathrm{I}_{0}\right)$ was plotted against their respective lipid: peptide molar ratio. SigmaPlot ${ }^{\circledR}$ (Systat Software Inc., San Jose, CA) was used for curve fitting of the plotted data. The saturation molar ratio of association between lipid and peptide was determined based on the lipid concentration where $90 \%$ of the plateau was reached. The number of peptide molecules associated with one micelle at saturation was calculated using the equation given below.

Number of PP molecules associated with one SSM=Aggregation number of micells/x;

where $\mathrm{x}$ stands for the number of lipid molecules at saturation.

\section{Determination of peptide secondary structure by circular dichroism spectroscopy}

Pancreatic polypeptide is known to possess some alpha helical secondary structure in aqueous media (34). The aim of this experiment was to determine if this conformation of PP is enhanced or retained in micelles (since alpha helix is the preferred structure for peptidereceptor interaction). The conformation of PP in phosphate buffered saline or when associated with SSM was determined using circular dichroism (CD) function of Jasco 710 spectropolarimeter (Jasco Inc., Easton, MD). Lipid and peptide concentration were kept constant at $1 \mathrm{mM}$ and $4 \mu \mathrm{M}$ respectively and the spectra were recorded between 190-260nm using $1 \mathrm{~cm}$ path length fused quartz cuvettes and a band width of $1 \mathrm{~nm}$. The number of accumulations per sample was three and the spectra were corrected for buffer and SSM scans and smoothed using Savitzky Golay algorithm. The effect of formulation $\mathrm{pH}$ (6.58.0) on the secondary structure of PP was also investigated using CD spectroscopy.

\section{Lyophilization study}

This study was conducted to determine whether it was feasible to lyophilize PP-SSM aqueous solution and evaluate the formulations that were prepared and reconstituted using different aqueous media (with or without sodium chloride) for their efficacy in retaining peptide load after lyophilization. SSM can be freeze-dried without the use of any cryoprotectant or lyoprotectant at $5-15 \mathrm{mM}$ lipid concentration (35). For this study, the lipid and peptide concentration were kept constant at $5 \mathrm{mM}$ and $143 \mu \mathrm{M}$ respectively to obtain a lipid: peptide molar ratio of 35: 1 . This ratio chosen was slightly above the 
saturation molar ratio of PP-SSM in phosphate buffered saline as determined by fluorescence experiments described earlier. Samples were prepared in $\mathrm{pH} 7.4$ phosphate buffer or phosphate buffered saline and stored overnight at $-80^{\circ} \mathrm{C}$ followed by freezing in liquid nitrogen for at least 3 minutes. The frozen samples were then lyophilized using the Labconco FreeZone ${ }^{\circledR} 6$ Litre FreezeDry System (Labconco, Kansas, MO). After overnight lyophilization, the samples were reconstituted by adding normal saline to samples prepared in phosphate buffer and sterile water to those prepared in phosphate buffered saline and swirled mechanically till complete dissolution. This was followed by incubation for $2 \mathrm{~h}$ at $25^{\circ} \mathrm{C}$ in the dark for equilibration. Particle size and distribution, fluorescence emission as well as secondary conformation of the samples were measured before and after lyophilization as described above. In this study, it was ensured that the final preparations of PP-SSM formulated either way, contained $0.9 \% \mathrm{w} / \mathrm{v}$ sodium chloride to maintain isotonicity of the injectable product with body fluids.

\section{Evaluation of stability of PP against proteolytic degradation when associated with SSM}

This study was performed to assess the stability of PP against proteolytic enzyme when it is self-associated with SSM as compared to peptide in buffer. Trypsin serves as a model proteolytic enzyme as it is known to cleave PP to produce four different tryptic digest products (36). In this study, $30 \mu \mathrm{M}$ of the peptide in buffer or in SSM were incubated with $30 \mathrm{nM}$ of trypsin at $37^{\circ} \mathrm{C}$ to obtain a 1: 1000 molar ratio of enzyme to peptide. Lipid concentration used for the study was $900 \mu \mathrm{M}$ in order to obtain lipid: peptide ratio of 30:1 (close to the saturation molar ratio of association between SSM and PP). Samples were incubated with trypsin for time ranging between $0-120$ minutes and tryptic digestion of PP was stopped by adding $10 \mu 1$ of $40 \%$ trifluoroacetic acid to the reaction mixture. The degradation of $\mathrm{PP}$ was then determined using reversed phase high pressure liquid chromatography (RP-HPLC) using LC20AB Prominence Liquid Chromatograph (Shimadzu Corporation, Kyoto, Japan) followed by UV detection using SPD-M20A Prominence Diode Array Detector (Shimadzu Corporation, Kyoto, Japan) at $276 \mathrm{~nm}$. The procedure was adopted and modified from previously published literature (36). Mobile phase used for detection were water with $0.2 \mathrm{mM}$ phosphoric acid (A) and acetonitrile with $0.2 \mathrm{mM}$ phosphoric acid (B). Samples were detected through a gradient elution of 5-30\% B in the first 10 minutes followed by $30-40 \%$ B over the next 20 minutes. To determine the degradation kinetics, \% PP remaining was plotted over time and the linear portion of the semi $\log$ graph was used to determine degradation rate and half-life of the peptide.

\section{Determination of bioactivity of PP-SSM in vitro}

The purpose of this study was to investigate whether bioactivity of PP was retained when it associated with SSM through assessment of inhibition of forskolin stimulated cAMP production in SK-N-MC (human neuroblastoma) cells which endogenously express PP specific Y4 receptors (37). For the study, cells were seeded at a density of $2 \times 10^{5}$ cells/well in a 24 well plate using eagle's minimum essential media (EMEM) containing $10 \%$ fetal bovine serum and $1 \%$ penicillin $(100 \mathrm{U} / \mathrm{ml}) /$ streptomycin $(100 \mu \mathrm{g} / \mathrm{ml})$. At the start of the study, the growth media was replaced with serum free media containing $0.1 \mathrm{mM}$ phosphodiesterase inhibitor 3-Isobutyl-1-methylxanthine (IBMX) and incubated for $1 \mathrm{~h}$ at $37^{\circ} \mathrm{C}$ humidified, $5 \% \mathrm{CO}_{2}$ atmosphere. At the end of the incubation period, PP in PBS or PP-SSM was added to the wells at different concentrations ranging from 1 to $100 \mathrm{nM}$. Approximately, 3 minutes later, forskolin was added to the wells to obtain a final concentration of $10 \mu \mathrm{M}$ in each well and the cells were incubated for additional 45 minutes at $37^{\circ} \mathrm{C}$ in humidified, $5 \% \mathrm{CO}_{2}$ atmosphere. Thereafter, the culture media was aspirated and cells were lyzed with $100 \mu \mathrm{l}$ of $0.1 \mathrm{M}$ hydrochloric acid followed by incubation for 20 minutes at room temperature. Cell lysates were collected, centrifuged to remove cell debris and the supernatant was used for quantifying cAMP using enzyme linked immunosorbent 
assay (ELISA) according to the manufacturer's protocol (cAMP EIA kit). The results obtained were normalized with total protein content measured using coomassie plus bradford assay (Thermo scientific, Rockford, IL). In the study, the negative control groups (cells that were not stimulated by forskolin) included buffer, empty micelles and PP-SSM containing highest respective concentration of lipid and peptide used in the experiment; while positive control used were cells treated with buffer alone and stimulated with forskolin.

\section{Data and statistical analysis}

All data are expressed as mean \pm standard deviation (S.D.). For the statistical analysis, student's T-test or one way analysis of variance (ANOVA) followed by Tukey's and Fisher least significant difference post-hoc test were used and a value of $\mathrm{p}<0.05$ was considered as statistical significance.

\section{RESULTS}

\section{Particle size distribution analysis}

The particle size distribution of PP in the presence or absence of SSM was evaluated using dynamic light scattering by both intensity and volume weighted Nicomp analysis. In the absence of SSM, bimodal large heterogeneous aggregates of PP were observed with mean hydrodynamic diameters of $98.3 \pm 17.9 \mathrm{~nm}$ and $773.3 \pm 163.45 \mathrm{~nm}$ (Figure 1A). However, in the presence of SSM, a monomodal distribution of particles was observed with a mean hydrodynamic diameter of $13.5 \pm 0.7 \mathrm{~nm}$ (Figure $1 \mathrm{~B}$ ) which was not significantly different from the size of empty micelles (Figure 1C).

\section{Effect of $\mathrm{pH}$ and sodium chloride on the association of peptide and micelles}

Further evaluation of association between PP and SSM in phosphate buffered saline ( $\mathrm{pH}$ 7.4) was performed by monitoring the fluorescence emission of tyrosine residues of the peptide that served as intrinsic fluorophores. In presence of micelles, a three fold increase in fluorescence emission was observed compared to the aqueous solution of the peptide alone (Figure 2).

The effect of $\mathrm{pH}$ and sodium chloride on the saturation molar ratios of association between PP and SSM and subsequently the number of peptide molecules associated with one micelle was determined in $0.9 \% \mathrm{w} / \mathrm{v}$ sodium chloride $(\mathrm{pH} 4.5-7.0)$ and in phosphate buffers of $\mathrm{pH}$ $6.5,7.4$ and 8.0 in the presence or absence of $0.9 \% \mathrm{w} / \mathrm{v}$ sodium chloride. Addition of increasing amount of lipid $(8 \mu \mathrm{M}-400 \mu \mathrm{M})$ to a constant peptide concentration $(4 \mu \mathrm{M})$ resulted in an initial rise in the fluorescence emission, which later plateaued in the presence of excessive lipid. As evident from the saturation curves, there was a steeper increase as well as higher normalized fluorescence emission intensity in the absence of sodium chloride (Figure 3) compared to samples in aqueous media containing sodium chloride (Figure 4). Consequently, samples prepared without sodium chloride had lower saturation molar ratio of association between PP and SSM implying presence of more peptide molecules associated with micelles in such formulations. The particle size of PP-SSM prepared in the absence of sodium chloride was smaller $(\sim 7.7 \mathrm{~nm})$ (Figure $7 \mathrm{Ba}$ ) compared to those prepared in the presence of sodium chloride ( 14nm) (Figure 1B). Our recent molecular dynamics simulation studies using NAMD package and CHARMM27 force field indicate that DSPE$\mathrm{PEG}_{2000}$ micelles with hydrodynamic diameter of $7.7 \mathrm{~nm}$ have an aggregation number of 20 in pure water (32). Therefore in this study, the number of peptide molecules associated with each micelle in the absence of sodium chloride was determined using an aggregation number of 20 while for formulations prepared in the presence of sodium chloride an aggregation number of 90 was used (24). Both conditions gave similar i.e. association number of 2-3 
peptide molecules per micelle at saturation (Table 1). Change in $\mathrm{pH}$ did not bring about any change in the peptide-micelle interaction both in the presence or absence of sodium chloride in the aqueous media.

\section{Determination of peptide secondary structure by circular dichroism spectroscopy}

The secondary structure of PP in the presence or absence of SSM was determined using near-UV circular dichroism spectroscopy. PP exhibited its characteristic alpha-helical conformation both in the presence or absence of SSM, indicating that the physiologically active secondary conformation of the peptide is retained in the micelles. Furthermore, association of PP with SSM resulted in an increase in alpha helicity as observed by increased negative CD signal for alpha helix bands at 208 and 222nm (Figure 5). The secondary structure of the peptide was enhanced in SSM compared to free peptide at all $\mathrm{pHs}$ studied (Figure 6).

\section{Lyophilization study}

For effective translation of a drug product to the clinics, it is essential to formulate products in such a way that they have acceptable shelf-life. Peptide and phospholipid solutions are prone to oxidative and hydrolytic degradation and are not stable for the stipulated period required for pharmaceutical products and therefore need to be stored in the dry form. Since we had observed a clear difference in peptide-micelle association based on the presence or absence of sodium chloride in the aqueous media of the formulation, we decided to test PPSSM prepared and reconstituted after freeze-drying in different aqueous media to evaluate whether such differences brought about any change in the peptide/micelle association of the final product and to identify the formulation that is most suitable for lyophilization. To this end, one sample was prepared in $\mathrm{pH} 7.4$ phosphate buffered saline and reconstituted using sterile water [A], while the other was prepared in $\mathrm{pH} 7.4$ phosphate buffer and reconstituted using normal saline [B]. A lipid: peptide molar ratio of 35: 1 was used for both samples to ensure maximum peptide loading in each micelle. Elegant freeze dried cakes of both samples were obtained after lyophilization. Analysis of particle size distribution before and after lyophilization revealed no significant change in the size distribution before and after lyophilization for samples prepared in phosphate buffered saline and reconstituted in sterile water (Figure 7A) with mean hydrodynamic diameters of $13.4 \pm 0.8 \mathrm{~nm}$ before lyophilization and $14.2 \pm 0.1 \mathrm{~nm}$ after lyophilization. However, in samples prepared in the absence of sodium chloride, smaller sized micelles were observed with a mean hydrodynamic diameter of $7.7 \pm 0.72 \mathrm{~nm}$; which after reconstitution with normal saline, had size in the normal range of $14.2 \pm 0.47 \mathrm{~nm}$ (Figure 7B).

The fluorescence emission of the samples prepared in the phosphate buffered saline decreased significantly after lyophilization which maybe due to dissociation of some peptide molecules from micelles during lyophilization. However, the fluorescence emission after lyophilization from PP-SSM samples that were prepared in phosphate buffer and reconstituted in normal saline did not decrease significantly indicating that the peptide was retained more effectively in this formulation (Figure 8). Circular dichroism studies before and after lyophilization did not demonstrate any change in the alpha-helicity of the peptide in samples prepared with or without sodium chloride and reconstituted using sterile water or normal saline respectively (Figure 9).

\section{Evaluation of stability of PP against proteolytic degradation when associated with SSM}

The study was conducted to determine whether association of PP with SSM affords any stability to the peptide against proteolytic degradation. To conduct the test, PP in buffer or in SSM were incubated with trypsin for different periods of time and the percent of PP remaining was determined based on the original amount of PP in the sample. Results of the 
study indicated that SSM significantly improved the stability of PP against proteolytic degradation at all the time points studied. This protective effect was more prominent during the first 15 minutes where the percent PP remaining in the solution was $~ 95 \%$ whereas only about $55 \%$ of PP remained un-degraded in PP in buffer samples (Figure 10). The degradation rate for PP and PP-SSM were calculated to be 0.028 and $0.011 \mathrm{~min}^{-1}$ respectively and the corresponding half-life of the peptide was calculated to be 24.8 and 63.0 minutes respectively. Therefore, in the presence of micelles, the stability of PP improved approximately 2.5 folds.

\section{Determination of bioactivity of PP-SSM in vitro}

Pancreatic polypeptide is known to inhibit cAMP production in cells. In this study, Y4 receptor binding and activation of PP in SSM was assessed and compared to peptide alone to evaluate whether bioactivity of the peptide is retained when it is associated with micelles. PP in buffer and PP-SSM significantly decreased forskolin stimulated cAMP production in SK$\mathrm{N}-\mathrm{MC}$ cells and to a similar extent as compared to positive control (Figure 11).

Approximately $40-50 \%$ reduction in cAMP concentration compared to positive control was observed for PP and PP-SSM at the doses tested. A peptide dose dependent inhibition of cAMP production was not observed. Treatment of SK-N-MC cells with empty micelles and PP-SSM corresponding to the highest respective concentration of lipid and peptide tested in the study, did not significantly change cAMP level as compared to the buffer treated group.

\section{DISCUSSION}

Pancreatic Polypeptide (PP) is a gut hormone released mainly in response to food ingestion. One of the elucidated functions of PP is its hypoglycemic activity mediated through reduction in glucose release from liver. Exogenous administration of PP has been shown to increase insulin binding sites in the liver which was later established to be due to significant increase in the gene transcription of beta subunit of insulin receptors (10). This suggests that PP can be used in the modulation and treatment of metabolic disorders such as diabetes and obesity. However, the therapeutic application of PP is restricted due to issues such as short plasma half-life, self-aggregation of the peptide in solution and lack of effective targeting to the desired site of action; and we anticipated circumventing this issue by delivering PP in SSM.

\section{Characterization of association between PP and SSM}

Peptide micelle interaction was characterized using particle size distribution and fluorescence emission study. Results from this study revealed that pancreatic polypeptide spontaneously associated with phospholipid micelles. The peptide formed heterogeneous aggregates in aqueous media. However, when incubated with micelles, formation of such peptide aggregates was abated and particles around the normal size of micelles were observed, indicating that peptide molecules preferentially interacted with phospholipid micelles and did not self-associate to form its own aggregates. This notion was corroborated through fluorescence studies that exploited the intrinsic fluorescence of the tyrosine residues in the peptide to determine peptide-micelle association. We observed that the fluorescence emission of the peptide increased approximately three folds in presence of phospholipid micelles. The increase in fluorescence is postulated to be due to association of individual peptide molecules with the micelles that reduces fluorescence quenching as observed in PP aggregates.

The peptide-micelle interaction did not vary according to aqueous media $\mathrm{pH}$ conditions but was influenced by the presence or absence of sodium chloride in the formulation. In the absence of sodium chloride, a lower saturation molar ratio of association was observed 
compared to formulations prepared in the presence of sodium chloride; however the number of peptide molecules associated with each micelle at saturation remained similar in both formulations. This can be explained on the basis of difference in properties of micelles prepared in the presence or absence of sodium chloride in the formulation. In the presence of sodium chloride, the phospholipid head groups of micelles are enveloped in a cloud of counterions, that decrease repulsion between negatively charged phosphate groups, increases aggregation number that results in increase in hydrodynamic size of micelles. Conversely, in the absence of strong counterions in the aqueous media, the negative charges on the phospholipids are not neutralized that leads to increased repulsion between phospholipids, decrease in aggregation number, thereby decrease in micelle size. This view has been substantiated through our recent experimental as well as molecular dynamics simulation studies, where we observed a decrease in micelle size and aggregation number of micelles prepared in the absence of strong counterions (32). Based on this rationale, formulations prepared in the presence of sodium chloride will contain large sized micelles but fewer in number while those prepared in absence of sodium chloride will contain small sized micelles but more in number, given the same amount of lipid is used in both cases. The abundance of micelles in the absence of sodium chloride increases the likelihood of interaction between peptide molecules and micelles that subsequently lowers the saturation molar ratio of association between SSM and PP. However, the number of peptide molecules associated with each micelle remains similar in both formulations because tighter stacking of lipids in large micelles decreases the available volume for peptide to reside whereas increased repulsion between phosphate headgroups in small sized micelles increases the available volume for peptide-micelle association. In addition to this, charge interaction between peptide and micelles is also deliberated to play a role in the association between SSM and PP. In the absence of sodium chloride, higher peptide-micelle interaction is observed due to electrostatic affinity between phospholipid head groups of micelles and charged amino acid residues on the peptide. However, in the presence of sodium chloride, charges on both entities are neutralized by counterions that abrogate charge based interaction between peptide and micelles and decrease association. Furthermore, sodium chloride is known to stabilize the alpha-helix of amphipathic peptides (38) that can decrease the driving hydrophobic force in peptide-micelle interaction.

\section{Peptide secondary structure in SSM}

Circular dichroism study revealed that the alpha helical secondary conformation of the peptide was enhanced when associated with micelles. This was evident from the increased negative bands corresponding to those for alpha-helical peaks and was observed for all pHs and in the presence or absence of sodium chloride in the aqueous media. These findings are in concordance with the observations of other researchers. Lerch et al. have observed that alpha-helical secondary structure of PP was stabilized when bound to dodecylphosphocholine micelles as compared to peptide in solution (39). With respect to effect of $\mathrm{pH}$ on change in peptide conformation, Tonan et al. showed that ellipticity of PP was not $\mathrm{pH}$ dependent above pH 5.0 (40) which is in agreement with our findings. Increased conformational stability of the peptide within the micelle offers the advantage of enhanced receptor interaction therefore enhanced bioactivity.

\section{Characterization of stability of PP-SSM towards Iyophilization}

Lyophilization of PP-SSM prepared in $\mathrm{pH} 7.4$ phosphate buffered saline resulted in a significant decrease in fluorescence emission after lyophilization. This was most likely due to dissociation of peptide molecules from the micelles upon freeze-drying that may result in their aggregation and subsequent fluorescence quenching. For formulations prepared in phosphate buffer and reconstituted in normal saline, no significant decrease in fluorescence emission was observed after lyophilization suggesting that peptide-micelle association is 
retained to a greater extent after lyophilization when PP-SSM is prepared in formulations not containing sodium chloride. A plausible reason for this observation is that PP-SSM prepared in the absence of sodium chloride interacts with each other through both electrostatic as well as hydrophobic interactions that strengthen peptide-micelle association and lead to reduced dissociation of peptide molecules from SSM during lyophilization. Based on this result, it is evident that only the formulation of PP-SSM prepared in the absence of sodium chloride and reconstituted after freeze-drying in normal saline is robust to the process of lyophilization. Therefore we propose that during development of final PP-

SSM product, the formulation should be prepared in aqueous media not containing sodium chloride and reconstituted after lyophilization in normal saline as this will ensure the stability of the peptide in micelles during freeze-drying.

\section{Stability enhancement of PP using SSM}

In the presence of SSM, the stability of PP was significantly improved against proteolytic degradation. An approximate 2.5 fold enhancement in stability of PP was observed compared to peptide alone in buffer when the samples were incubated with trypsin. The peptide is postulated to reside in the PEG corona of the micelles, which provide a steric barrier and prevent recognition and degradation of the peptide by proteolytic enzymes, thus improve half-life of the peptide. We believe that in an in vivo setting, these phospholipid micelles will protect PP against rapid proteolytic degradation and make them longcirculating that will lead to enhanced activity and requirement of less frequent dosing to achieve therapeutic efficacy.

\section{Retention of in vitro bioactivity of PP in SSM}

In vitro bioactivity studies of PP and PP-SSM indicated that the bioactivity of PP was retained when associated with micelles. A significant inhibition in cAMP levels were observed at all the doses tested for the peptide. The extent of inhibition of cAMP was similar for PP in buffer and PP in SSM which is expected as the studies were conducted in serum free media, thus in an environment lacking proteolytic activity. A dose dependent inhibition of cAMP production was not observed. This is postulated to be due to weak expression of $\mathrm{Y} 4$ receptors in SK-N-MC cells which may have resulted in saturation of the receptors available for binding by PP at the concentrations tested.

Overall, the study exhibited that association of PP with SSM does not hamper interaction of the peptide with its receptors. PP-SSM is not anticipated to be cytotoxic to the cells as the peptide has no reported cytotoxic activity and SSM is not toxic to cells up to $150 \mu \mathrm{M}$ lipid concentration (unpublished data) which is much higher than the maximum lipid concentration used for this study.

Taken together, these studies demonstrated the feasibility of formulating PP-SSM wherein the peptide remained in its active alpha-helical conformation and had improved stability against proteolytic degradation without any compromise in its bioactivity. The formulation when prepared in the absence of sodium chloride was robust to freeze-drying and should be considered when the product is being further developed for use in clinics. SSM formulations can be easily scaled up and any change in peptide-micelle interaction due to large scale production is not foreseeable because the peptide molecules self-associate with micelles that is driven by the internal energy of the system which remains constant regardless of the preparation scale. The nanomedicine can also be prepared with high peptide load as warranted for preclinical testing, thus facilitating easy transition of the product for clinical use. 


\section{CONCLUSION}

A novel formulation of pancreatic polypeptide in phosholipid micelles has been developed and characterized. The peptide was shown to self-associate with sterically stabilized phospholipid micelles that subverts its propensity to aggregate and provides conformational stability to the peptide molecules which could lead to enhanced receptor interaction and bioactivity. Peptide-micelle interaction as well as the effectiveness of lyophilization was influenced by the presence or absence of sodium chloride in the aqueous media of the formulation and this information can prove valuable during the development of the final product. The stability of the peptide against proteolytic degradation was significantly improved when it was associated with micelles and the peptide retained its bioactivity in the micellar formulation. Increased stability of PP in micelles precludes the need of administering large doses of the peptide through continuous intravenous infusion for achieving therapeutic efficacy. Currently, we are further evaluating this nanomedicine for its efficacy on animals with the ultimate goal to transition it to the clinics for the treatment of metabolic disorders associated with deficiency of PP such as pancreatogenic diabetes.

\section{Acknowledgments}

The authors thank Dr. Bao-Shiang Lee for synthesizing PP used in the research. The study was supported in part by NIH grant CA121797 and UIC university scholar award.

\section{ABBREVIATIONS}

$\begin{array}{ll}\text { ANOVA } & \text { Analysis of Variance } \\ \text { CAMP } & \text { Cyclic Adenosine Monophosphate } \\ \text { CD } & \text { Circular Dichroism } \\ \text { CMC } & \text { Critical Micellar Concentration } \\ \text { CP } & \text { Chronic Pancreatitis } \\ \text { DLS } & \text { Dynamic Light Scattering } \\ \text { DSPE-PEG 2000 } & \text { Distearoyl Phosphatidylethanolamine-Polyethylene Glycol } 2000 \\ \text { EMEM } & \text { Eagle's Minimum Essential Media } \\ \text { FD } & \text { Freeze-Drying } \\ \text { IBMX } & \text { 3-Isobutyl-1-methylxanthine } \\ \text { NPY } & \text { Neuropeptide Y } \\ \text { NS } & \text { Normal Saline } \\ \text { PB } & \text { Phosphate Buffer } \\ \text { PBS } & \text { Phosphate Buffered Saline } \\ \text { PD } & \text { Pancreatogenic Diabetes } \\ \text { PP } & \text { Pancreatic Polypeptide } \\ \text { RP-HPLC } & \text { Reversed Phase High Pressure Liquid Chromatography } \\ \text { SD } & \text { Standard Deviation } \\ \text { SSM } & \text { Sterically Stabilized Micelles }\end{array}$




\section{References}

1. Lonovics J, Devitt P, Watson LC, Rayford PL, Thompson JC. Pancreatic polypeptide. A review. Arch Surg. 1981; 116(10):1256-1264. [PubMed: 7025798]

2. Schmidt PT, Naslund E, Gryback P, Jacobsson H, Holst JJ, Hilsted L, et al. A role for pancreatic polypeptide in the regulation of gastric emptying and short-term metabolic control. J Clin Endocrinol Metab. 2005; 90(9):5241-5246. [PubMed: 15998783]

3. Langlois A, Corring T, Levenez F, Cuber JC, Chayvialle JA. Effects of pancreatic polypeptide on biliary flow and bile acid secretion stimulated by secretin and cholecystokinin in the conscious pig. Regul Pept. 1990; 27(1):139-147. [PubMed: 2309045]

4. Lerch M, Kamimori H, Folkers G, Aguilar MI, Beck-Sickinger AG, Zerbe O. Strongly altered receptor binding properties in PP and NPY chimeras are accompanied by changes in structure and membrane binding. Biochemistry. 2005; 44(25):9255-9264. [PubMed: 15966750]

5. Bard JA, Walker MW, Branchek TA, Weinshank RL. Cloning and functional expression of a human Y4 subtype receptor for pancreatic polypeptide, neuropeptide Y, and peptide YY. J Biol Chem. 1995; 270(45):26762-26765. [PubMed: 7592911]

6. Seymour NE, Spector SA, Andersen DK, Elm MS, Whitcomb DC. Overexpression of Hepatic Pancreatic Polypeptide Receptors in Chronic Pancreatitis. J Surg Res. 1998; 4;76(1):47-52.

7. Hennig R, Kekis PB, Friess H, Adrian TE, Buchler MW. Pancreatic polypeptide in pancreatitis. Peptides. 2002; 23(2):331-338. [PubMed: 11825647]

8. Adrian TE, Besterman HS, Mallinson CN, Garalotis C, Bloom SR. Impaired pancreatic polypeptide release in chronic pancreatitis with steatorrhoea. Gut. 1979; 20(2):98-101. [PubMed: 428832]

9. Cui Y, Andersen DK. Pancreatogenic Diabetes: Special Considerations for Management. Pancreatology. 2011; 11(3):279-294. [PubMed: 21757968]

10. Seymour, NE.; Andersen, DK. Pancreatic Polypeptide and Glucose Metabolism. In: Greeley, editor. Gastrointestinal Endocrinology. New Jersey: Humana Press; 1999. p. 321-334.

11. Seymour NE, Volpert AR, Andersen DK. Regulation of hepatic insulin receptors by pancreatic polypeptide in fasting and feeding. J Surg Res. 1996; 65(1):1-4. [PubMed: 8895598]

12. Seymour NE, Volpert AR, Lee EL, Andersen DK, Hernandez C. Alterations in hepatocyte insulin binding in chronic pancreatitis: effects of pancreatic polypeptide. Am J Surg. 1995; 169(1):105109. [PubMed: 7817978]

13. Asakawa A, Inui A, Yuzuriha H, Ueno N, Katsuura G, Fujimiya M, et al. Characterization of the effects of pancreatic polypeptide in the regulation of energy balance. Gastroenterology. 2003; 124(5):1325-1336. [PubMed: 12730873]

14. Steppan CM, Lazar MA. Resistin and obesity-associated insulin resistance. Trends Endocrinol Metab. 2002; 13(1):18-23. [PubMed: 11750858]

15. Adrych K, Smoczynski M, Sledzinski T, Dettlaff-Pokora A, Goyke E, Swierczynski J. Increased serum resistin concentration in patients with chronic pancreatitis: possible cause of pancreatic fibrosis. J Clin Gastroenterol. 2009; 43(1):63-68. [PubMed: 18827713]

16. Andersen DK. Mechanisms and emerging treatments of the metabolic complications of chronic pancreatitis. Pancreas. 2007; 35(1):1-15. [PubMed: 17575539]

17. Brunicardi FC, Chaiken RL, Ryan AS, Seymour NE, Hoffmann JA, Lebovitz HE, et al. Pancreatic polypeptide administration improves abnormal glucose metabolism in patients with chronic pancreatitis. J Clin Endocrinol Metab. 1996; 81(10):3566-3572. [PubMed: 8855802]

18. Sun YS, Brunicardi FC, Druck P, Walfisch S, Berlin SA, Chance RE, et al. Reversal of abnormal glucose metabolism in chronic pancreatitis by administration of pancreatic polypeptide. The American Journal of Surgery. 1986; 151(1):130-140.

19. Seymour NE, Brunicardi FC, Chaiken RL, Lebovitz HE, Chance RE, Gingerich RL, et al. Reversal of abnormal glucose production after pancreatic resection by pancreatic polypeptide administration in man. Surgery. 1988; 104(2):119-129. [PubMed: 3041640]

20. Brunicardi FC, Chaiken RL, Ryan AS, Seymour NE, Hoffmann JA, Lebovitz HE, et al. Pancreatic polypeptide administration improves abnormal glucose metabolism in patients with chronic pancreatitis. J Clin Endocrinol Metab. 1996; 81(10):3566-3572. [PubMed: 8855802] 
21. Adrian TE, Greenberg GR, Besterman HS, Bloom SR. Pharmacokinetics of pancreatic polypeptide in man. Gut. 1978; 19(10):907-909. [PubMed: 568585]

22. Baxter J, Minnion J, Shilto-Cuenco J, Tan T, Murphy K, Ghatei M, et al. Pancreatic polypeptide: a novel substrate for the endopeptidase neprilysin. Endocrine Abstracts. 2010; 21:P133.

23. Swierczek JS, Pawlik W, Konturek SJ, Gustaw P, Dobrzanska M, Bielanski W, et al. Organ removal and disappearance half-time of synthetic human pancreatic polypeptide. Digestion. 1982; 25(3):197-200. [PubMed: 7160551]

24. Ashok B, Arleth L, Hjelm RP, Rubinstein I, Onyuksel H. In vitro characterization of PEGylated phospholipid micelles for improved drug solubilization: effects of PEG chain length and PC incorporation. J Pharm Sci. 2004; 93(10):2476-2487. [PubMed: 15349957]

25. Krishnadas A, Rubinstein I, Onyuksel H. Sterically Stabilized Phospholipid Mixed Micelles: In Vitro Evaluation as a Novel Carrier for Water-Insoluble Drugs. Pharm Res. 2003; 20(2):297-302. [PubMed: 12636171]

26. Onyuksel H, Jeon E, Rubinstein I. Nanomicellar paclitaxel increases cytotoxicity of multidrug resistant breast cancer cells. Cancer Lett. 2009; 274(2):327-330. [PubMed: 19022562]

27. Onyuksel H, Sejourne F, Suzuki H, Rubinstein I. Human VIP-alpha: a long-acting, biocompatible and biodegradable peptide nanomedicine for essential hypertension. Peptides. 2006; 27(9):22712275. [PubMed: 16621151]

28. Lim SB, Rubinstein I, Sadikot RT, Artwohl JE, Onyuksel H. A novel peptide nanomedicine against acute lung injury: GLP-1 in phospholipid micelles. Pharm Res. 2011; 28(3):662-672. [PubMed: 21108040]

29. Koo OM, Rubinstein I, Onyuksel H. Actively targeted low-dose camptothecin as a safe, longacting, disease-modifying nanomedicine for rheumatoid arthritis. Pharm Res. 2011; 28(4):776787. [PubMed: 21132352]

30. Koo OM, Rubinstein I, Onyuksel H. Camptothecin in sterically stabilized phospholipid micelles: A novel nanomedicine. Nanomedicine: Nanotechnology, Biology and Medicine. 2005; 1(1):77-84.

31. Kuzmis A, Lim SB, Desai E, Jeon E, Lee BS, Rubinstein I, et al. Micellar nanomedicine of human neuropeptide Y. Nanomedicine. 2011; 7(4):464-471. [PubMed: 21272667]

32. Vukovic L, Khatib FA, Drake SP, Madriaga A, Brandenburg KS, Kral P, et al. Structure and dynamics of highly PEG-ylated sterically stabilized micelles in aqueous media. J Am Chem Soc. 2011; 133(34):13481-13488. [PubMed: 21780810]

33. Kanazawa I, Hamaguchi K. Unfolding by temperature and guanidine hydrochloride of chicken pancreatic polypeptide. J Biochem. 1986; 100(1):207-212. [PubMed: 3759931]

34. Glover ID, Barlow DJ, Pitts JE, Wood SP, Tickle IJ, Blundell TL, et al. Conformational studies on the pancreatic polypeptide hormone family. Eur J Biochem. 1984; 142(2):379-385. [PubMed: 6745282]

35. Lim SB, Rubinstein I, Önyüksel H. Freeze drying of peptide drugs self-associated with longcirculating, biocompatible and biodegradable sterically stabilized phospholipid nanomicelles. Int J Pharm. 2008; 356(1-2):345-350. [PubMed: 18289811]

36. Taylor TC, Thompson DO, Ebner KE, Kimmel JR, Rawitch AB. An immunochemical study of avian pancreatic polypeptide: the nature of the principle epitope. Mol Immunol. 1988; 25(10):96173. [PubMed: 2464136]

37. Li A, Ritter S. Functional expression of neuropeptide Y receptors in human neuroblastoma cells. Regul Pept. 2005; 129(1-3):119-124. [PubMed: 15927706]

38. Lazo ND, Downing DT. Stabilization of amphipathic alpha-helical and beta-helical conformations in synthetic peptides in the presence and absence of ionic interactions. J Pept Res. 1998; 51(1):8589. [PubMed: 9495596]

39. Lerch M, Gafner V, Bader R, Christen B, Folkers G, Zerbe O. Bovine Pancreatic Polypeptide (bPP) Undergoes Significant Changes in Conformation and Dynamics upon Binding to DPC Micelles. J Mol Biol. 2002; 322(5):1117-1133. [PubMed: 12367532]

40. Tonan K, Kawata Y, Hamaguchi K. Conformations of isolated fragments of pancreatic polypeptide. Biochemistry. 1990; 29(18):4424-4429. [PubMed: 2350546] 


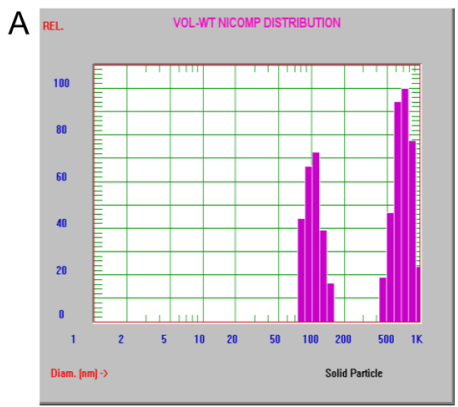

B

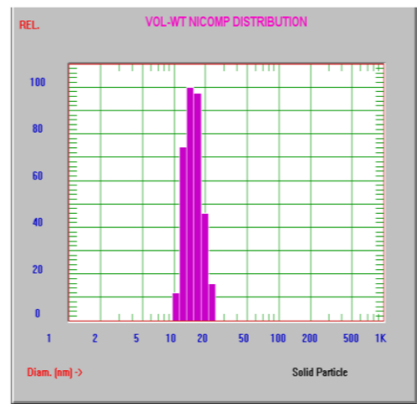

C

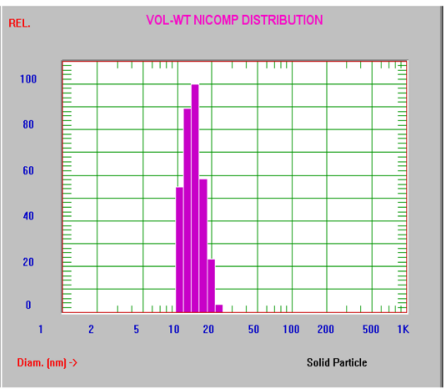

Fig 1. Particle size distribution of PP in presence or absence of SSM

Representative Nicomp figures showing particle size distribution of (A) $4 \mu \mathrm{M}$ PP in PBS;

(B) PP-SSM; and (C) Empty SSM (120 $\mu$ M DSPE-PEG 2000$)$. 


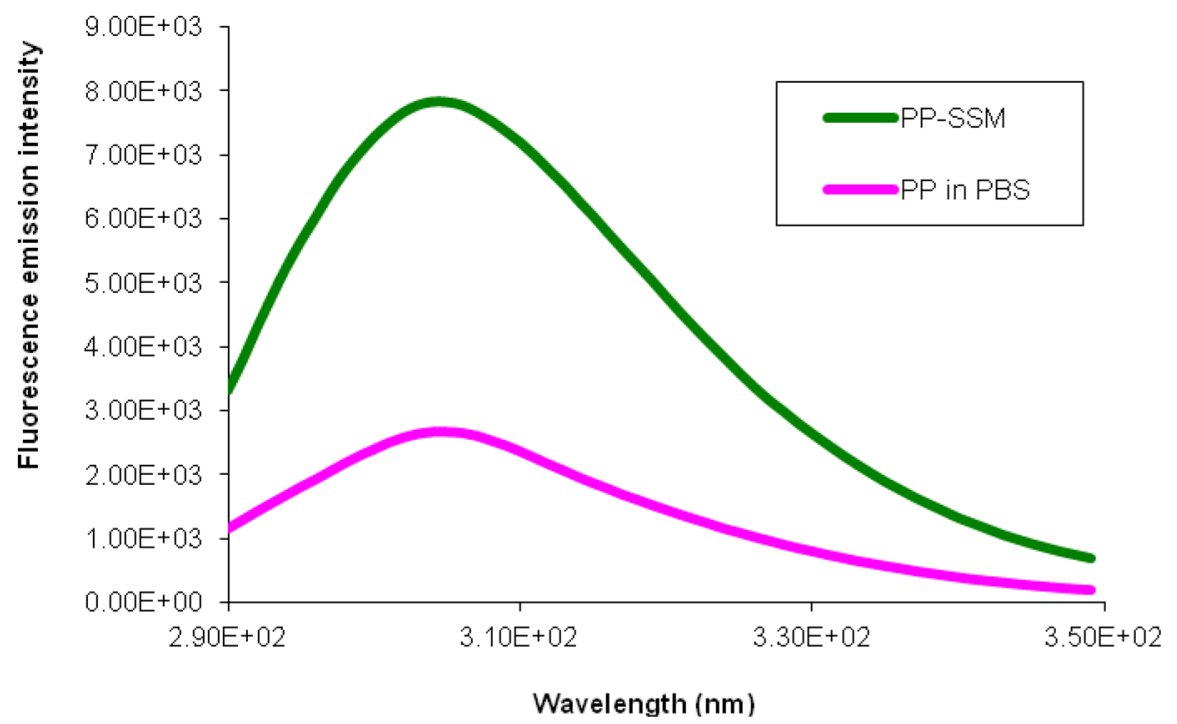

Fig 2. Fluorescence emission of PP in presence or absence of SSM

Fluorescence emission spectra of PP in phosphate buffered saline and when incubated with SSM. Fluorescence emission spectra of PP in phosphate buffered saline and when incubated with SSM (4 $\mu$ M PP and $120 \mu \mathrm{M}$ lipid). 


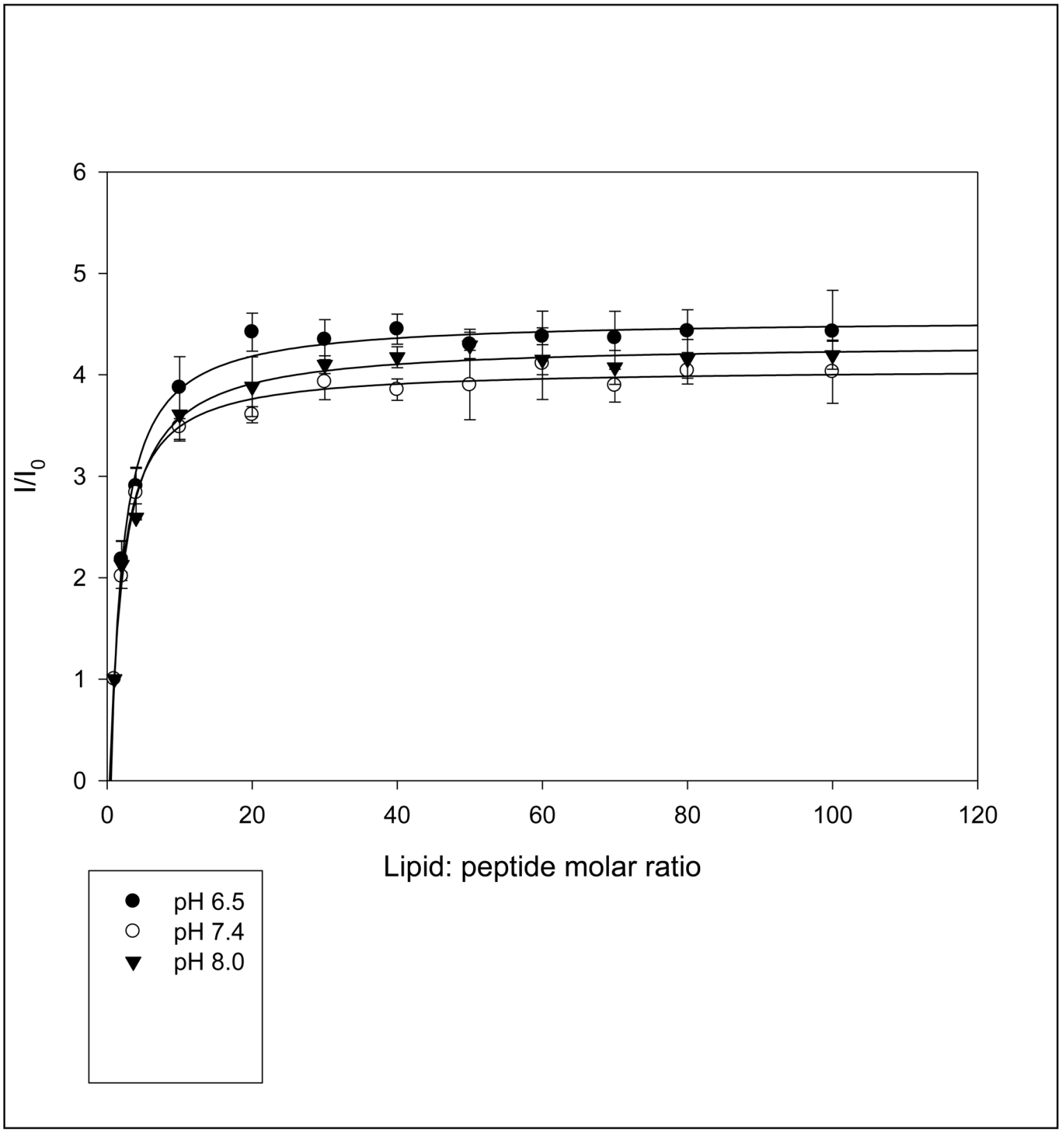

Fig 3. Saturation curves of PP-SSM in buffers of different $\mathrm{pH}$ in the absence of sodium chloride Comparative plots for the determination of association molar ratios of PP-SSM at various $\mathrm{pH}$ in the absence of sodium chloride. Plot represents fluorescence enhancement ratio $\left(\mathrm{I} / \mathrm{I}_{0}\right)$ of PP with increasing amount of DSPE-PEG 2000 . PP concentration kept constant at $4 \mu \mathrm{M}$. All data are mean \pm S.D. $(n=3)$. Filled circle represents $\mathrm{pH} 6.5$, empty circle represents $\mathrm{pH}$ 7.4 and inverted filled triangle represents $\mathrm{pH} 8.0$ 


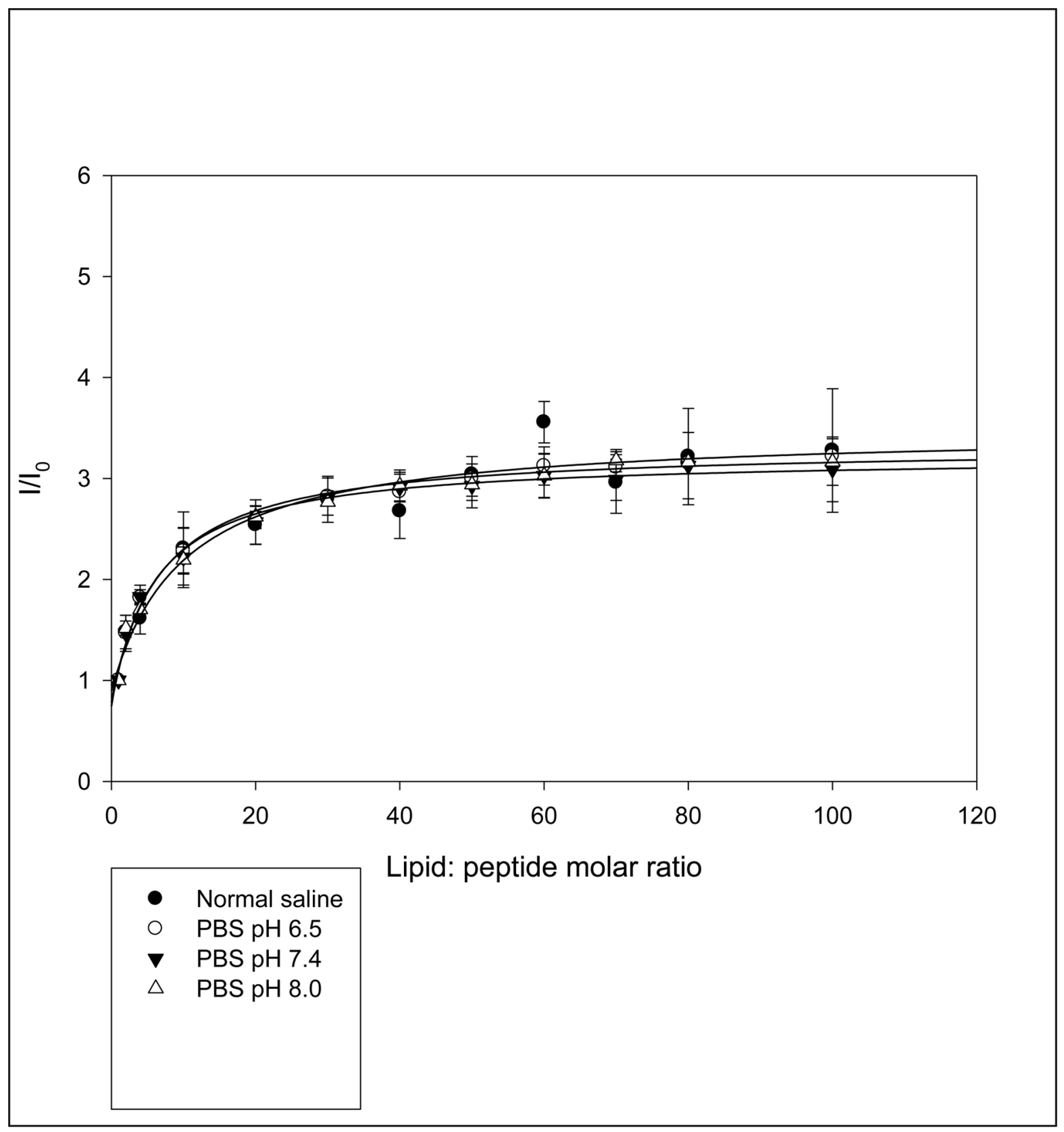

Fig 4. Saturation curves of PP-SSM in normal saline or buffers of different $\mathrm{pH}$ in the presence of sodium chloride

Comparative plots for the determination of association molar ratios of PP-SSM at various $\mathrm{pH}$ in the presence of sodium chloride $(0.9 \% \mathrm{w} / \mathrm{v})$. Plot represents fluorescence enhancement ratio $\left(\mathrm{I} / \mathrm{I}_{0}\right)$ of PP with increasing amount of $\mathrm{DSPE}-\mathrm{PEG}_{2000}$. PP concentration kept constant at $4 \mu \mathrm{M}$. All data are mean \pm S.D. $(n=3)$. Filled circle represents normal saline ( $\mathrm{pH} 4.5-7)$, empty circle represents $\mathrm{pH} 6.5$, inverted filled triangle represents $\mathrm{pH} 7.4$ and empty triangle represents $\mathrm{pH}$ 8.0. 


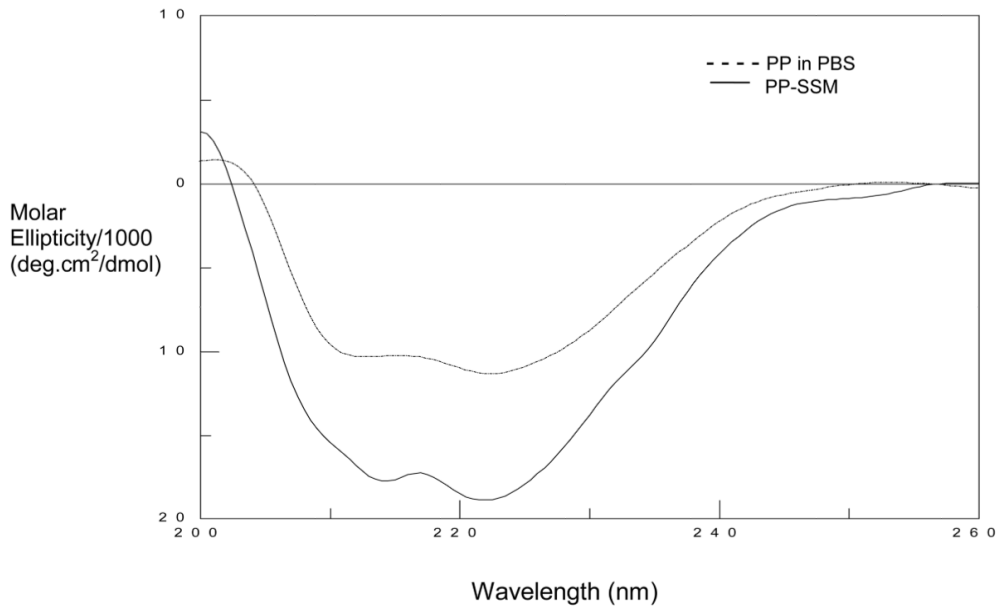

Fig 5. Secondary structure of PP in presence or absence of SSM

Representative circular dichroism spectra of $\mathrm{PP}(4 \mu \mathrm{M})$ in phosphate buffered saline $(\mathrm{pH}$ 7.4) and in SSM (1mM DSPE-PEG 2000 ) [Alpha helical secondary structures shown with characteristic negative bands at 208 and $222 \mathrm{~nm}]$. 

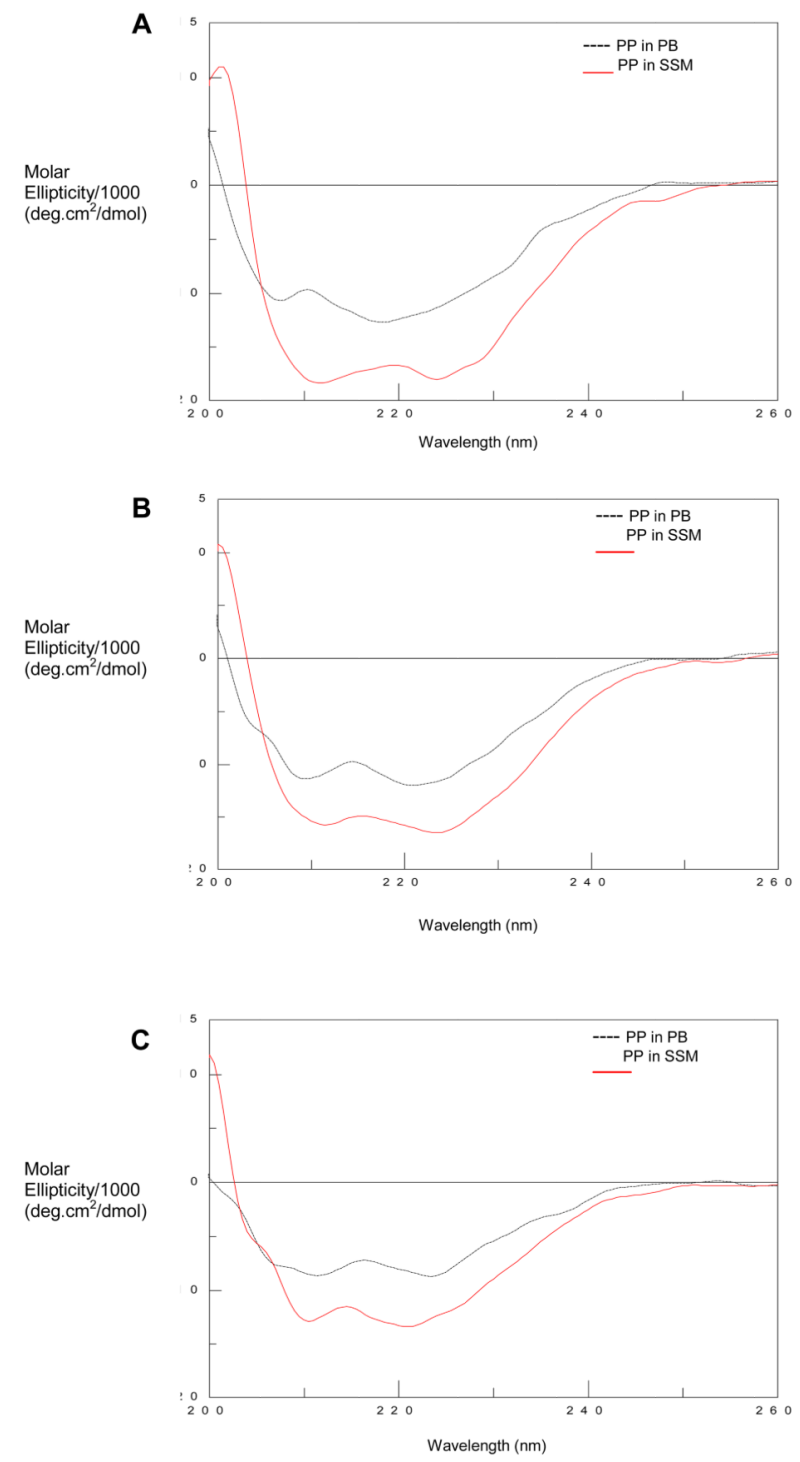

Fig 6. Secondary structure of $\mathrm{PP}$ at different $\mathrm{pHs}$ in presence or absence of SSM Circular dichroism spectra of PP $(4 \mu \mathrm{M})$ in phosphate buffer $(\mathrm{PB})$ not containing sodium chloride and in SSM (1mM DSPE-PEG 2000 ) A) pH 6.5; B) pH 7.4; and C) pH 8.0. [Alpha helical secondary structures shown with characteristic negative bands at 208 and $222 \mathrm{~nm}$ ]. 
A

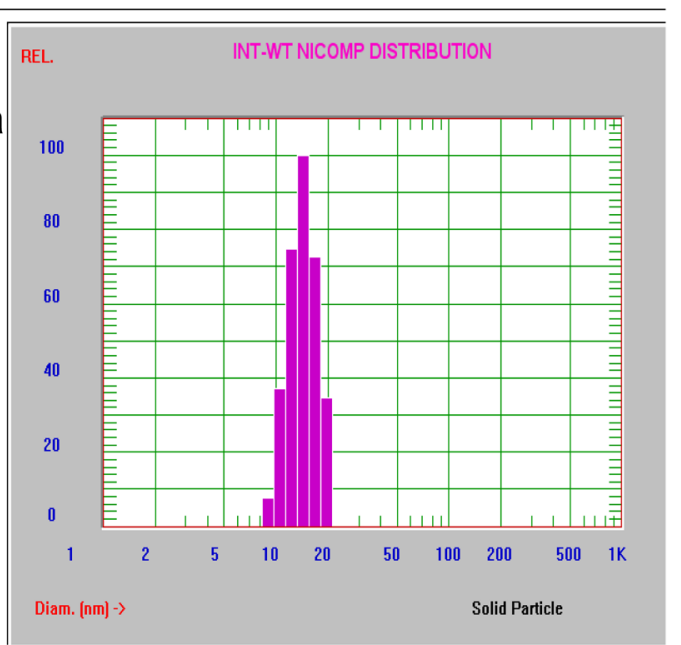

B

a

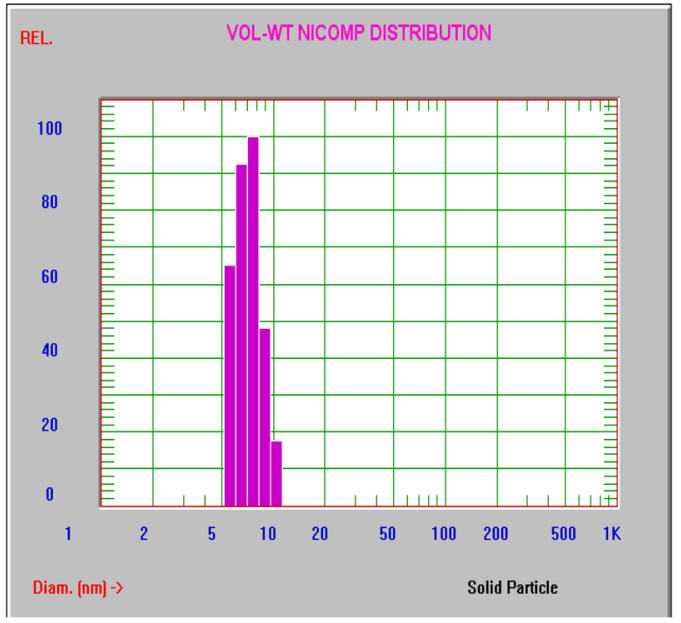

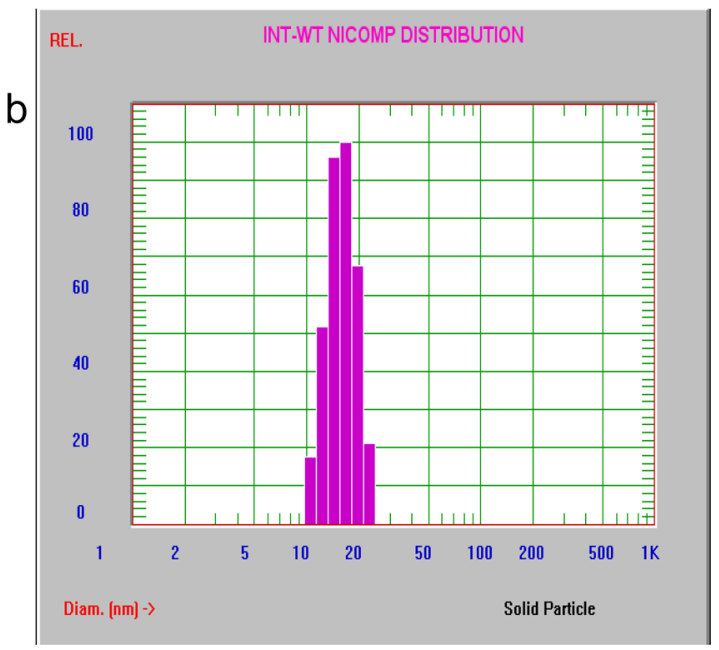

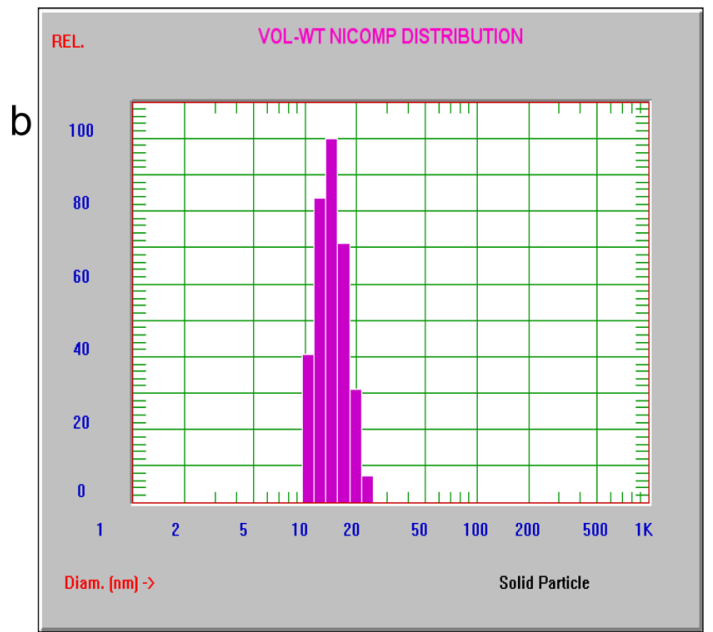

Fig 7. Particle size distribution of PP-SSM before and after lyophilization Representative Nicomp figures showing particle size distribution of PP-SSM at lipid: peptide molar ratio of 35: 1 (a) before and (b) after freeze drying. (A) Samples prepared in phosphate buffered saline and reconstituted using sterile water; (B) samples prepared in phosphate buffer and reconstituted using normal saline. Lipid and peptide concentration kept constant at $5 \mathrm{mM}$ and $143 \mu \mathrm{M}$ for all samples. 


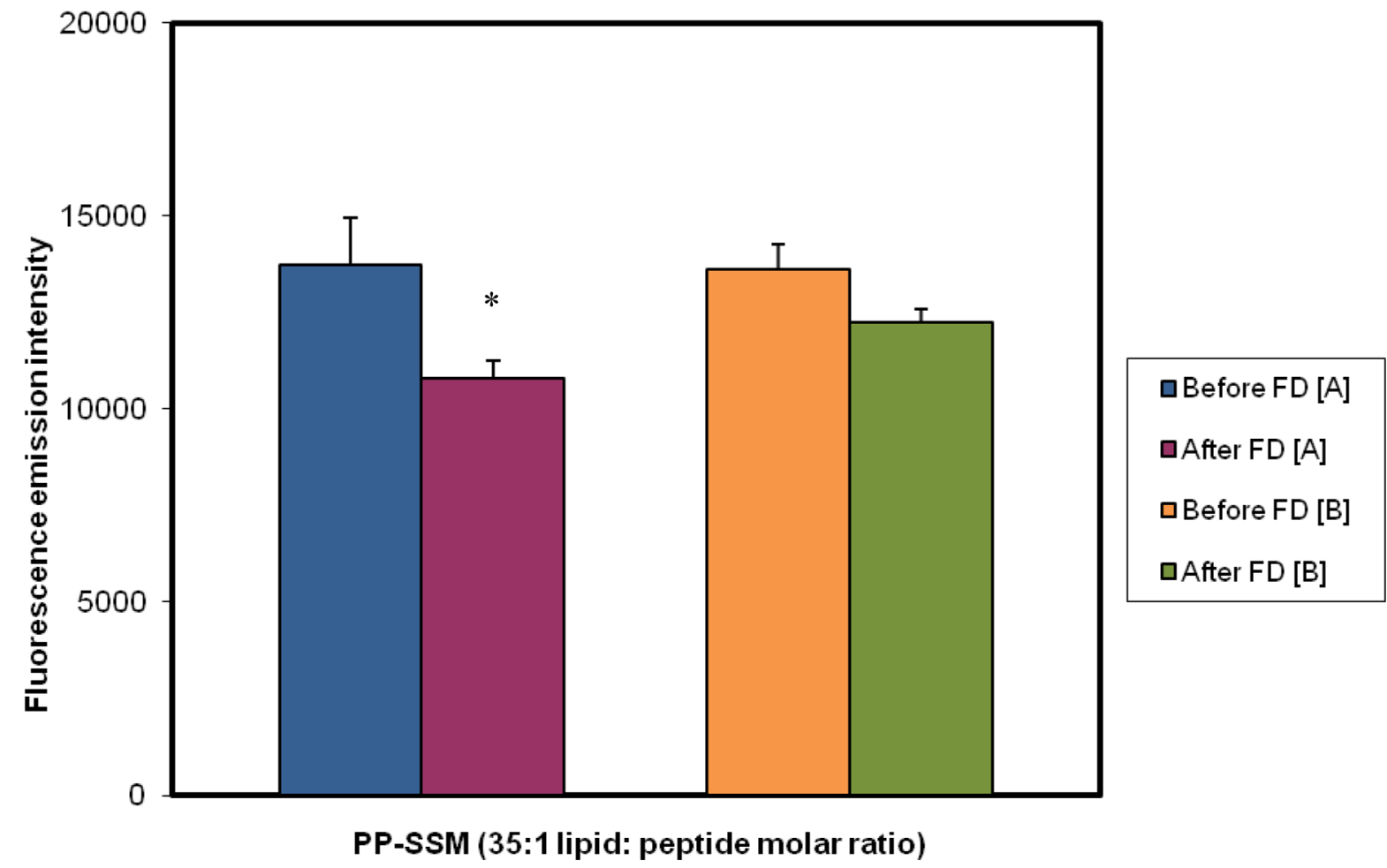

Fig 8. Fluorescence emission of PP-SSM before and after lyophilization

Fluorescence emission of PP-SSM before and after freeze drying (FD) at 35: 1 lipid: peptide molar ratios; [A] samples prepared in phosphate buffered saline (pH 7.4) and reconstituted in sterile water; $[\mathrm{B}]$ samples prepared in phosphate buffer $(\mathrm{pH} 7.4)$ and reconstituted using normal saline $(\mathrm{n}=3)$. Lipid and peptide concentration kept constant at $5 \mathrm{mM}$ and $143 \mu \mathrm{M}$ respectively for all samples. All results are mean \pm S.D. ${ }^{*} \mathrm{p}<0.05$ in comparison to fluorescence emission of PP-SSM before lyophilization ( $n=3$ /group). 

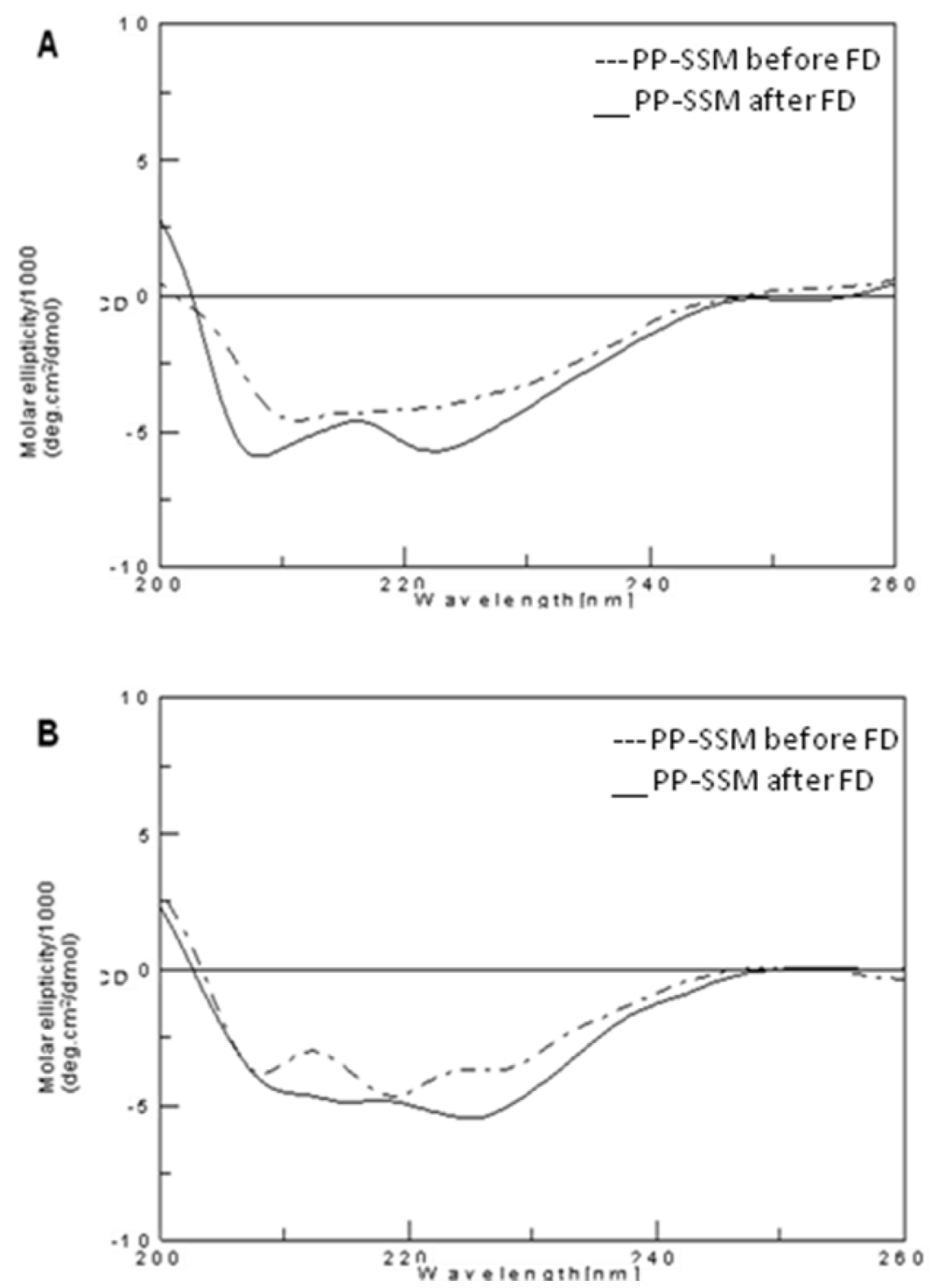

Fig 9. Secondary structure of PP before and after lyophilization

Representative CD spectra of PP in buffer and in SSM for samples prepared in [A] pH 7.4 $\mathrm{PBS}$ and reconstituted using sterile water and $[\mathrm{B}]$ prepared in $\mathrm{pH} 7.4$ phosphate buffer without sodium chloride and reconstituted using normal saline. Dotted line represents spectra before lyophilization while solid line represents spectra after lyophilization. 


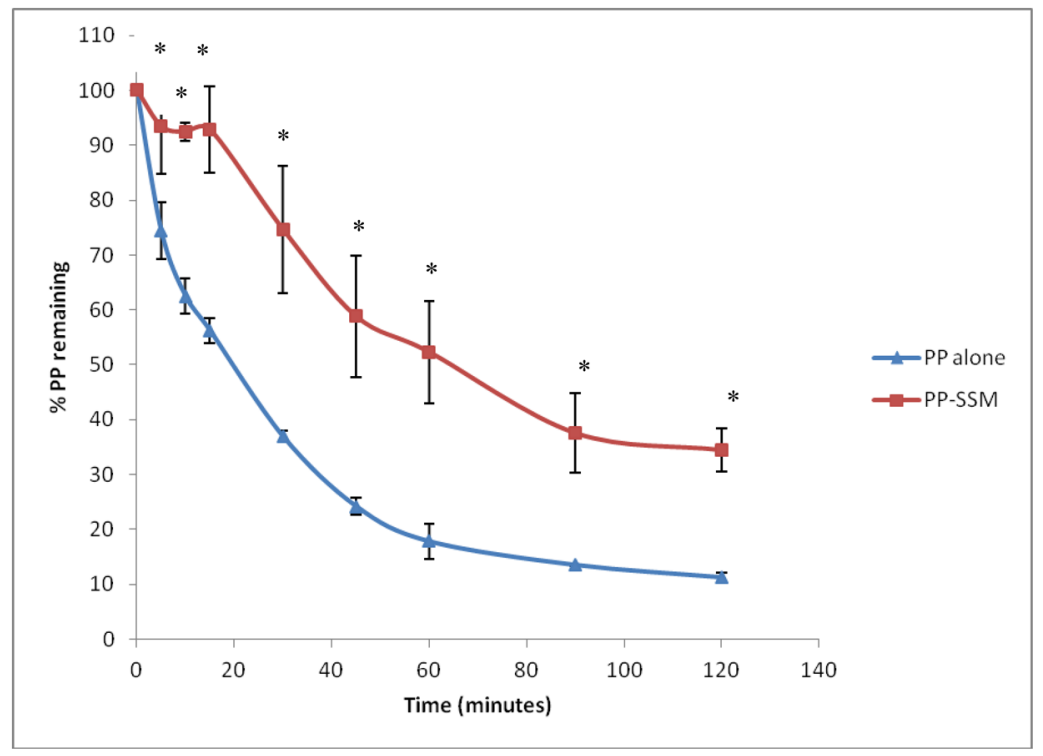

Fig 10. Tryptic digestion kinetics of PP and PP-SSM

Degradation kinetics of PP in presence or absence of SSM upon incubation with trypsin $(n=3)$. * represents statistical significance at $\mathrm{p}<0.05$ in comparison to PP in buffer for the same time point. 


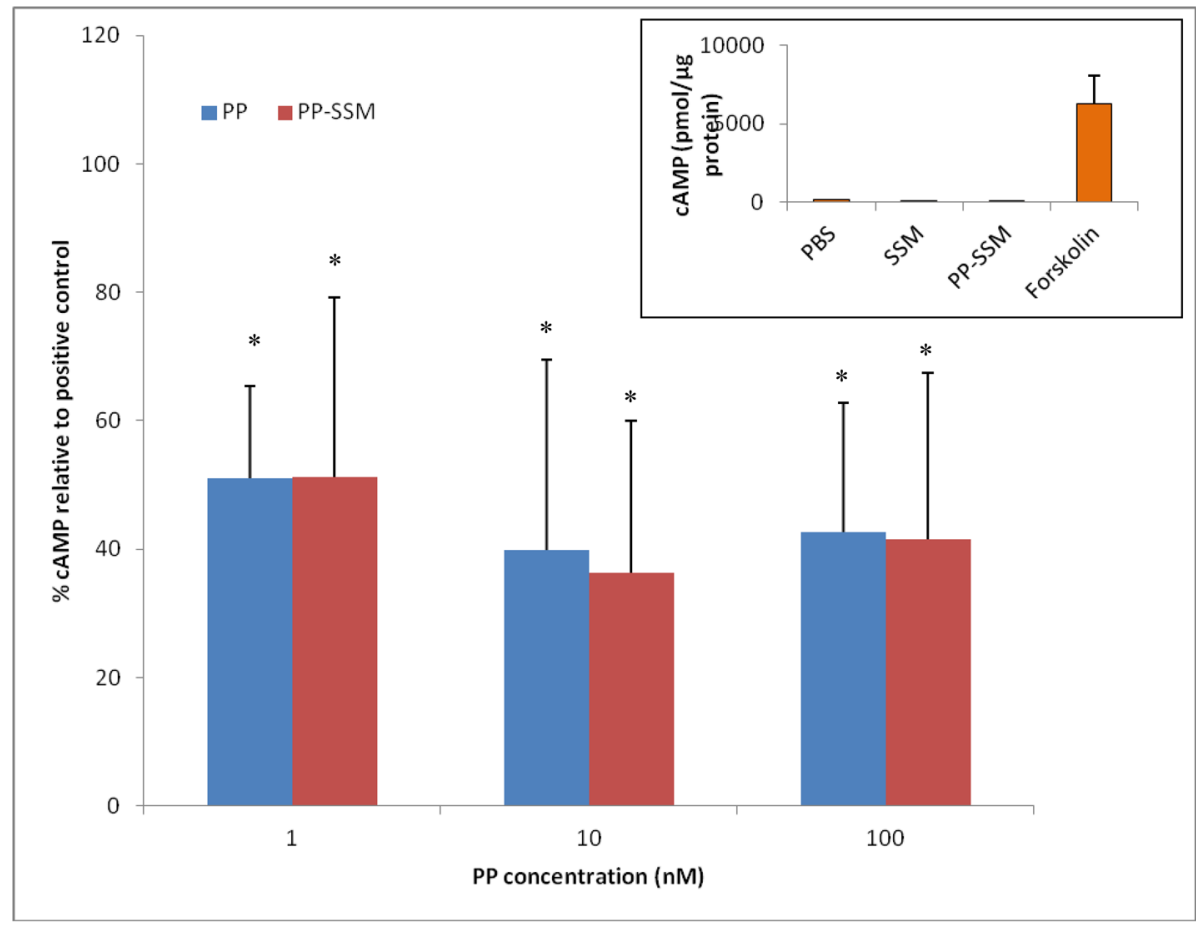

Fig 11. Inhibition of forskolin stimulated cyclic AMP production by PP and PP-SSM Percent inhibition of forskolin stimulated cAMP response in SK-N-MC cells by PP in buffer and PP-SSM at peptide doses of 1, 10 and 100nM (Normalized to forskolin treated group). * indicates statistical significance at $\mathrm{p}<0.05$ compared to forskolin treated group (positive control; PP $=0 \mathrm{nM}$ ). Inset represents normalized cAMP concentration in SK-N-MC cells treated with PBS, empty SSM, PP-SSM and forskolin. 


\section{Table 1}

Effect of $\mathrm{pH}$ and presence or absence of sodium chloride in the aqueous media on the association of PP with SSM

\begin{tabular}{|c|c|c|c|c|}
\hline \multirow{2}{*}{$\mathbf{p H}$} & \multicolumn{2}{|c|}{ Absence of sodium chloride } & \multicolumn{2}{c|}{ Presence of sodium chloride } \\
\cline { 2 - 5 } & $\begin{array}{c}\text { Molar ratio of association } \\
\text { (Lipid: PP) }\end{array}$ & $\begin{array}{c}\text { \# PP molecules per } \\
\text { SSM }\end{array}$ & $\begin{array}{c}\text { Molar ratio of association } \\
\text { (Lipid: PP) }\end{array}$ & $\begin{array}{c}\text { \# PP molecules per } \\
\text { SSM }\end{array}$ \\
\hline $\begin{array}{c}\text { Normal saline } \\
\mathbf{4 . 5}-\mathbf{7 . 0})\end{array}$ & - & - & $41: 1$ & 2 \\
\hline $\mathbf{6 . 5}$ & $8: 1$ & 3 & $38: 1$ & 2 \\
\hline $\mathbf{7 . 4}$ & $9: 1$ & 2 & $32: 1$ & 3 \\
\hline $\mathbf{8 . 0}$ & $11: 1$ & 2 & $49: 1$ & 2 \\
\hline
\end{tabular}

Relation between $\mathrm{pH}$ and presence or absence of sodium chloride on the molar ratio of association between PP and SSM at saturation and the number of peptide molecules associated with one micelle at saturation. 